Article

\title{
Biochar Is Comparable to Dicyandiamide in the Mitigation of Nitrous Oxide Emissions from Camellia oleifera Abel. Fields
}

\author{
Bangliang Deng ${ }^{1,2}$, Haifu Fang ${ }^{1}$, Ningfei Jiang ${ }^{3}$, Weixun Feng ${ }^{1}$, Laicong Luo ${ }^{1}$, Jiawei Wang ${ }^{1}$, \\ Hua Wang ${ }^{4}$, Dongnan $\mathrm{Hu}^{1}{ }^{1}$, Xiaomin Guo ${ }^{1}$ and Ling Zhang ${ }^{1, *}$ \\ 1 Key Laboratory of Silviculture, College of Forestry, Jiangxi Agricultural University, Nanchang 330045, China; \\ bangliangdeng@gmail.com (B.D.); fanghaifu11@163.com (H.F.); fwx1754090341@126.com (W.F.); \\ Luolaicong@126.com (L.L.); wjw_bjfu@163.com (J.W.); dnhu98@163.com (D.H.); gxmjxau@163.com (X.G.) \\ 2 Department of Plant Pathology, North Carolina State University, Raleigh, NC 27695, USA \\ 3 Seed Management Station, Jiande Agricultural and Rural Burea, Jiande 311600, China; \\ jiangningfei2009@163.com \\ 4 College of Land Resources and Environment, Jiangxi Agricultural University, Nanchang 330045, China; \\ mengyiwanghua@sina.com \\ * Correspondence: lingzhang09@126.com; Tel.: +86-0791-8381-3243
}

Received: 25 October 2019; Accepted: 25 November 2019; Published: 27 November 2019

\begin{abstract}
Research Highlights: Intensive nitrogen $(\mathrm{N})$ application for agricultural purposes has substantially increased soil nitrous oxide $\left(\mathrm{N}_{2} \mathrm{O}\right)$ emissions. Agricultural soil has great potential in the reduction of $\mathrm{N}_{2} \mathrm{O}$ emissions, and applications of biochar and nitrification inhibitors may be useful for mitigating agricultural soil $\mathrm{N}_{2} \mathrm{O}$ emissions. Background and Objectives: Camellia oleifera Abel. is an important woody oil plant in China. However, intensive $\mathrm{N}$ input in C. oleifera silviculture has increased the risk of soil $\mathrm{N}_{2} \mathrm{O}$ emissions. As an important greenhouse gas, $\mathrm{N}_{2} \mathrm{O}$ is characterized by a global warming potential at a 100-year scale that is 265 times that of carbon dioxide. Thus, mitigation of soil $\mathrm{N}_{2} \mathrm{O}$ emissions, especially fertilized soils, will be crucial for reducing climate change. Materials and Methods: Here, we conducted an in situ study over 12 months to examine the effects of C. oleifera fruit shell-derived biochar and dicyandiamide (DCD) on soil $\mathrm{N}_{2} \mathrm{O}$ emissions from a C. oleifera field with intensive $\mathrm{N}$ application. Results: A three-fold increase of cumulative soil $\mathrm{N}_{2} \mathrm{O}$ emissions was observed following $\mathrm{N}$ application. Cumulative $\mathrm{N}_{2} \mathrm{O}$ emissions from the field with $\mathrm{N}$ fertilization were reduced by $36 \%$ and $44 \%$ with biochar and DCD, respectively. While $\mathrm{N}_{2} \mathrm{O}$ emissions were slightly deceased by biochar, the decrease was comparable to that by DCD. Conclusions: Results indicated that biochar may mitigate soil $\mathrm{N}_{2} \mathrm{O}$ emissions substantially and similarly to DCD under specific conditions. This result should be examined by prolonged and multi-site studies before it can be generalized to broader scales.
\end{abstract}

Keywords: biochar; Camellia oleifera; DCD; nitrification inhibitor; nitrous oxide

\section{Introduction}

Increased atmospheric greenhouse gases (GHGs) as a result of human activities contribute substantially to global warming. Nitrous oxide $\left(\mathrm{N}_{2} \mathrm{O}\right)$ is an important component of GHGs [1] and is a dominant ozone-depleting substance [2]. Concentrations of atmospheric $\mathrm{N}_{2} \mathrm{O}$ increased from $270 \mathrm{ppb}$ in the 18th century to a new high at $329.9 \mathrm{ppb}$ in 2017 [3]. Specifically, the global warming potential at a 100-year scale of $\mathrm{N}_{2} \mathrm{O}$ is 265 times that of carbon dioxide [1]. Considering its important role in global warming, reduction of $\mathrm{N}_{2} \mathrm{O}$ emissions is crucial for the mitigation of global climate change. 
Soil is the largest source of $\mathrm{N}_{2} \mathrm{O}$ emissions at $13 \mathrm{Tg} \mathrm{N} \mathrm{N}_{2} \mathrm{O}-\mathrm{N}$ year ${ }^{-1}$. Human activities have contributed $7 \mathrm{Tg} \mathrm{N}_{2} \mathrm{O}-\mathrm{N}$ year ${ }^{-1}$ thus far in the 21st century [4]. Intensive nitrogen $(\mathrm{N})$ applications for agricultural purposes have induced input of $79 \mathrm{Tg}$ synthetic $\mathrm{N}$ and $7.4 \mathrm{Tg} \mathrm{N}$ of livestock manure per year $[5,6]$. Therefore, agricultural soil has large potential in the reduction of $\mathrm{N}_{2} \mathrm{O}$ emissions and hence for the mitigation of global climate change.

Biochar and nitrification inhibitor applications are useful strategies for $\mathrm{N}_{2} \mathrm{O}$ emission mitigation [7-10]. Biochar is produced by slow pyrolysis of organic matter under high temperatures and an anaerobic environment [11]. Biochar application reduced $\mathrm{N}_{2} \mathrm{O}$ emissions caused by $\mathrm{N}$ fertilization by $33 \%$ [7]; this was ascribed to increased soil $\mathrm{pH}$ [12] or $\mathrm{N}$ immobilization [7]. In addition, $70 \%$ of $\mathrm{N}_{2} \mathrm{O}$ emissions are emitted from microbial-driven nitrification and denitrification processes [4], which could be effectively inhibited by nitrification inhibitors. Nitrification inhibitors are a class of organic compounds that inhibit the activity of nitrifying nitrifiers, including synthetic nitrification inhibitors such as dicyandiamide (DCD), nitrapyrin, and 3, 4-dimethylpyrazole phosphate, and biological nitrification inhibitors such as methyl 3-(4-hydroxyphenyl) propionate [13] and brachialactone [14]. Nitrification inhibitors reduced $\mathrm{N}_{2} \mathrm{O}$ emissions by $44 \%$ via inhibition of nitrifying nitrifiers [15]. As a commonly used nitrification inhibitor, DCD deactivates the activity of ammonium monooxygenase enzyme (a copper co-factor enzyme), and hence $\mathrm{N}_{2} \mathrm{O}$ emissions [16].

Camellia oleifera Abel. is one of the world's four main woody edible oil crops, with a long cultivation history and wide cultivation area in subtropical China [17] due to the beneficial effects of its oil on human health [18]. C. oleifera is mainly cultivated in Typic Hapludult Ultisols (red soil) with lower soil fertility $[17,19]$. Therefore, intensive $\mathrm{N}$ input has been used to increase the yield of $C$. oleifera oil. However, large amounts of $\mathrm{N}$ input increase the risk of nitrate $\mathrm{N}\left(\mathrm{NO}_{3}{ }^{-}-\mathrm{N}\right)$ leaching and gaseous $\mathrm{N}$ losses, such as $\mathrm{N}_{2} \mathrm{O}$ emissions and ammonia volatilization $[20,21]$. While large amounts of $C$. oleifera fruit shells have been dumped without use, it might be an ideal feedstock for producing biochar for the mitigation of $\mathrm{N}_{2} \mathrm{O}$ emissions [22].

Here, we conducted study using biochar derived from C. oleifera fruit shells and DCD to examine their effects in the mitigation of $\mathrm{N}_{2} \mathrm{O}$ emissions from a C. oleifera field with intensive ammonium nitrate $\left(\mathrm{NH}_{4} \mathrm{NO}_{3}\right)$ fertilization. We predicted that $C$. oleifera fruit shell-derived biochar or DCD may effectively mitigate soil $\mathrm{N}_{2} \mathrm{O}$ emissions.

\section{Materials and Methods}

\subsection{Study Site and Soil Collection}

This study was conducted at a C. oleifera plantation covering 200 ha in Yongxiu county, Jiangxi province, China $\left(29.16^{\circ} \mathrm{N}, 115.77^{\circ} \mathrm{E}\right)$ from 25 February 2017 to 16 March 2018. The C. oleifera plantation has been intensively managed more than 10 years, with each individual tree distributed $2 \mathrm{~m}$ or $3 \mathrm{~m}$ apart. Compound fertilizer with $14 \% \mathrm{~N}$ was applied at the rate of $300 \mathrm{mg} \mathrm{plant}^{-1}$. In this region, there is a subtropical monsoon climate with a mean annual precipitation of $1561 \mathrm{~mm}$ and a mean annual air temperature of $17.5^{\circ} \mathrm{C}$ (the monthly mean temperature ranges from $2.4^{\circ} \mathrm{C}$ in January to $33.4^{\circ} \mathrm{C}$ in July) (http://www.worldclim.org). Soil was classified as Typic Hapludult (red soil). Soil characteristics were obtained by collecting soil samples from 12 randomly selected sites and pooled together for measurement. The basic characteristics were as follows: bulk density, $1.42 \mathrm{~g} \mathrm{~cm}^{-3} ; \mathrm{pH}$, 4.45; total organic carbon (TOC), $11.06 \mathrm{~g} \mathrm{~kg}^{-1}$; total $\mathrm{N}(\mathrm{TN}), 1.18 \mathrm{~g} \mathrm{~kg}^{-1}$; dissolved organic carbon (DOC), $0.28 \mathrm{~g} \mathrm{~kg}^{-1}$; dissolved organic $\mathrm{N}(\mathrm{DON}), 39.78 \mathrm{mg} \mathrm{kg}^{-1}$; ammonium N $\left(\mathrm{NH}_{4}{ }^{+}-\mathrm{N}\right), 4.52 \mathrm{mg} \mathrm{kg}^{-1}$; $\mathrm{NO}_{3}{ }^{-}-\mathrm{N}, 1.37 \mathrm{mg} \mathrm{kg}^{-1}$.

\subsection{Experimental Design and Field Procedures}

This study was conducted using a randomized design with four treatments (including Control, $\mathrm{N}$ only, $\mathrm{N}$ with Biochar, $\mathrm{N}$ with $\mathrm{DCD})$ and four replications $(N=16$, four soil amelioration treatment $\times$ four replicates). Biochar was produced by pyrolyzing $C$. oleifera fruit shell at $450{ }^{\circ} \mathrm{C}$ without oxygen 
for $1 \mathrm{~h}$ and was applied at the rate of $500 \mathrm{~g} \mathrm{plant}^{-1}$ (equivalent to $10 \mathrm{tha}^{-1}$ ). Biochar characteristics were: $\mathrm{pH}, 9.49$; TOC, $743.89 \mathrm{~g} \mathrm{~kg}^{-1}$; TN, $5.14 \mathrm{~g} \mathrm{~kg}^{-1}$; DOC, $1.57 \mathrm{~g} \mathrm{~kg}^{-1}$; DON, $14.28 \mathrm{mg} \mathrm{kg}^{-1} ; \mathrm{NH}_{4}{ }^{+}-\mathrm{N}$, $2.24 \mathrm{mg} \mathrm{kg}^{-1} ; \mathrm{NO}_{3}{ }^{-}-\mathrm{N}, 2.65 \mathrm{mg} \mathrm{kg}^{-1}$. DCD was applied by $2 \%(\mathrm{DCD} / \mathrm{N})$ [22]. Two years before the study, the studied area was intensively managed but no fertilization was applied. In the study, $\mathrm{N}$ was applied by $20 \mathrm{~g} \mathrm{NH}_{4} \mathrm{NO}_{3}-\mathrm{N}_{\text {plant }}{ }^{-1}$ (equivalent to $400 \mathrm{~kg} \mathrm{NH}_{4} \mathrm{NO}_{3}-\mathrm{N} \mathrm{ha}^{-1}$ ). Sixteen C. oleifera trees with similar size (mean ground diameter: $6.52 \mathrm{~cm}$ ) were randomly selected and $0.5 \mathrm{~m}^{2}$ plots were established under the crown of each plant for measurement of $\mathrm{N}_{2} \mathrm{O}$ fluxes. Nitrogen, biochar, or DCD were thoroughly mixed and applied in all plots.

Static opaque chamber method was used for measurement of $\mathrm{N}_{2} \mathrm{O}$ fluxes. Plastic collars with a groove (inner diameter $=16.7 \mathrm{~cm}$, height $=10 \mathrm{~cm}$, groove $=9 \mathrm{~cm}$ ) were installed inside each plot. The collar groove was filled with water to seal the open-bottomed chamber (inner diameter $=19.5 \mathrm{~cm}$, height $=80 \mathrm{~cm}$ ) covered with foam and aluminum for minimizing temperature variation [23]. Gas samples were collected at minutes $0,5,10$, and $15 \mathrm{~min}$ from chamber closing using a syringe, and were stored in aluminum foil gas sample bags before analysis.

Fluxes of $\mathrm{N}_{2} \mathrm{O}$ were measured 21 times from 25 February, 2017 to 16 March, 2018 at days 4, 8, $12,19,26,32,46,62,77,93,111,130,140,161,175,190,210,248,287,339$, and 384. Air temperature, soil temperature, and moisture $\left(10 \mathrm{~cm}\right.$ depth) were monitored simultaneously when $\mathrm{N}_{2} \mathrm{O}$ fluxes were measured. Meanwhile, soil $\mathrm{NH}_{4}{ }^{+}-\mathrm{N}$ and $\mathrm{NO}_{3}{ }^{-}-\mathrm{N}(0-20 \mathrm{~cm}$ layer) were measured nine times over the study on days $62,93,130,161,210,248,287,339$, and 384 .

\subsection{Analysis of Soil and Biochar Characteristics}

Concentrations of soil and biochar $\mathrm{NH}_{4}{ }^{+}-\mathrm{N}$ and $\mathrm{NO}_{3}{ }^{-}-\mathrm{N}$ were extracted by $2 \mathrm{~mol} \mathrm{~L}{ }^{-1} \mathrm{KCl}$ solution and measured by a discrete analyzer (Smartchem 200, Rome, Italy). Dissolved organic carbon and DON were extracted by $0.5 \mathrm{~mol} \mathrm{~L}^{-1} \mathrm{~K}_{2} \mathrm{SO}_{4}$ and measured by element analyzer (Multi N/C 3100, Jena Germany). $\mathrm{pH}$ was measured by soil $(1: 2.5, w / w)$ or biochar $(1: 5, w / w)$ suspensions using $\mathrm{pH}$ meter and air-dried samples passed through 0.2-mm sieve (Mettler Toledo, Shanghai, China). Total organic carbon and TN were also analyzed by an element analyzer (Variomax CNS Analyzer, Elementar GmbH, Hanau, Germany) using samples passed through a 0.15-mm sieve.

\subsection{Measurement of Soil $\mathrm{N}_{2} \mathrm{O}$ Emission Rates and Cumulative Soil $\mathrm{N}_{2} \mathrm{O}$ Emissions}

Nitrous oxide concentration in each sample was determined using gas chromatograph (Agilent 7890B, Santa Clara, CA, USA). In situ measurements were conducted on sunny days with minimal partial pressure of water vapor. Nitrous oxide fluxes $\left(F, \mu \mathrm{g} \mathrm{m}^{-2} \mathrm{~h}^{-1}\right)$ were calculated by $[23,24]$ :

$$
F=P \times V \times \frac{\Delta c}{\Delta t} \times \frac{1}{R T} \times M \times \frac{1}{S}
$$

where $P$ stands for standard atmospheric pressure $(\mathrm{Pa})$ (which should be adjusted if partial pressure of water vapor of chamber air taken into consideration [25]), $V$ refers to the volume of chamber headspace $\left(\mathrm{m}^{3}\right), \Delta c / \Delta t$ means the rate of $\mathrm{N}_{2} \mathrm{O}(\mathrm{ppb})$ concentration change with time based on linear regressions [26,27], $R$ stands for universal gas constant $\left(\mathrm{m}^{3} \mathrm{~mol}^{-1} \mathrm{~K}^{-1}\right), T$ is the absolute air temperature $(\mathrm{K}), M$ means the molecular mass of $\mathrm{N}_{2} \mathrm{O}\left(\mathrm{g} \mathrm{mol}^{-1}\right)$, and $S$ indicates the collar area $\left(\mathrm{m}^{2}\right)$.

Cumulative soil $\mathrm{N}_{2} \mathrm{O}$ emissions $\left(E, \mu \mathrm{g} \mathrm{m}^{-2}\right)$ were calculated by [28]:

$$
E=\sum_{i=1}^{n} \frac{\left(F_{i}+F_{i+1}\right)}{2} \times\left(t_{i+1}-t_{i}\right) \times 24
$$

where $F$ indicates soil $\mathrm{N}_{2} \mathrm{O}$ emission rates $\left(\mu \mathrm{g} \mathrm{m}^{-2} \mathrm{~h}^{-1}\right), i$ means the $i$ th measurement, $\left(t_{i+1}-t_{i}\right)$ refers to the time span (days) between two measurements, and $n$ means the total number of the measurements. 


\subsection{Statistical Analysis}

One-way analysis of variance (ANOVA) was performed to examine dependence of cumulative $\mathrm{N}_{2} \mathrm{O}$ emissions on $\mathrm{N}$, biochar and DCD treatments. Repeated-measures ANOVA was used to examine dependence of soil temperature, moisture, $\mathrm{NH}_{4}{ }^{+}-\mathrm{N}, \mathrm{NO}_{3}{ }^{-}-\mathrm{N}$ and $\mathrm{N}_{2} \mathrm{O}$ emission rates on biochar and DCD treatments. Tukey's honestly significant difference (HSD) tests were used for identifying the significant differences among treatments in ANOVA. Follow-up contrasts were conducted for significant repeated-measures ANOVA results. Pairwise correlation analysis was applied to examine relationship between environment factor, inorganic $\mathrm{N}$ and soil $\mathrm{N}_{2} \mathrm{O}$ emission rate. All statistical analyses were carried out using JMP 9.0. Software (Gary, NC, USA) at $\alpha=0.05$.

\section{Results}

Application of $\mathrm{N}$, biochar, or DCD significantly influenced soil $\mathrm{N}_{2} \mathrm{O}$ emission rates $(F=8.34$, $p=0.0029)$ and cumulative $\mathrm{N}_{2} \mathrm{O}$ emissions $(F=6.68, p=0.0067)$ compared to control from the $C$. oleifera field. No significant results were observed in soil temperature, moisture, $\mathrm{NH}_{4}{ }^{+}-\mathrm{N}$, and $\mathrm{NO}_{3}{ }^{-}-\mathrm{N}$ (Figures 1 and 2). Compared with $\mathrm{N}$ treatment, $\mathrm{N}+\mathrm{DCD}(F=7.94, p=0.0155)$ or $\mathrm{N}+\operatorname{biochar}(F=$ $5.69, p=0.0344)$ treatments showed lower soil $\mathrm{N}_{2} \mathrm{O}$ emission rates, but no significant differences were observed between $\mathrm{N}+\mathrm{DCD}$ and $\mathrm{N}+$ biochar treatments $(F=0.19, p=0.67$; Figure 3). Overall, $\mathrm{N}$, biochar, or DCD treatments significantly impacted soil $\mathrm{N}_{2} \mathrm{O}$ emission rates over the 12-month study ( $F$ $=10.11, p=0.0013$; Figure 3).

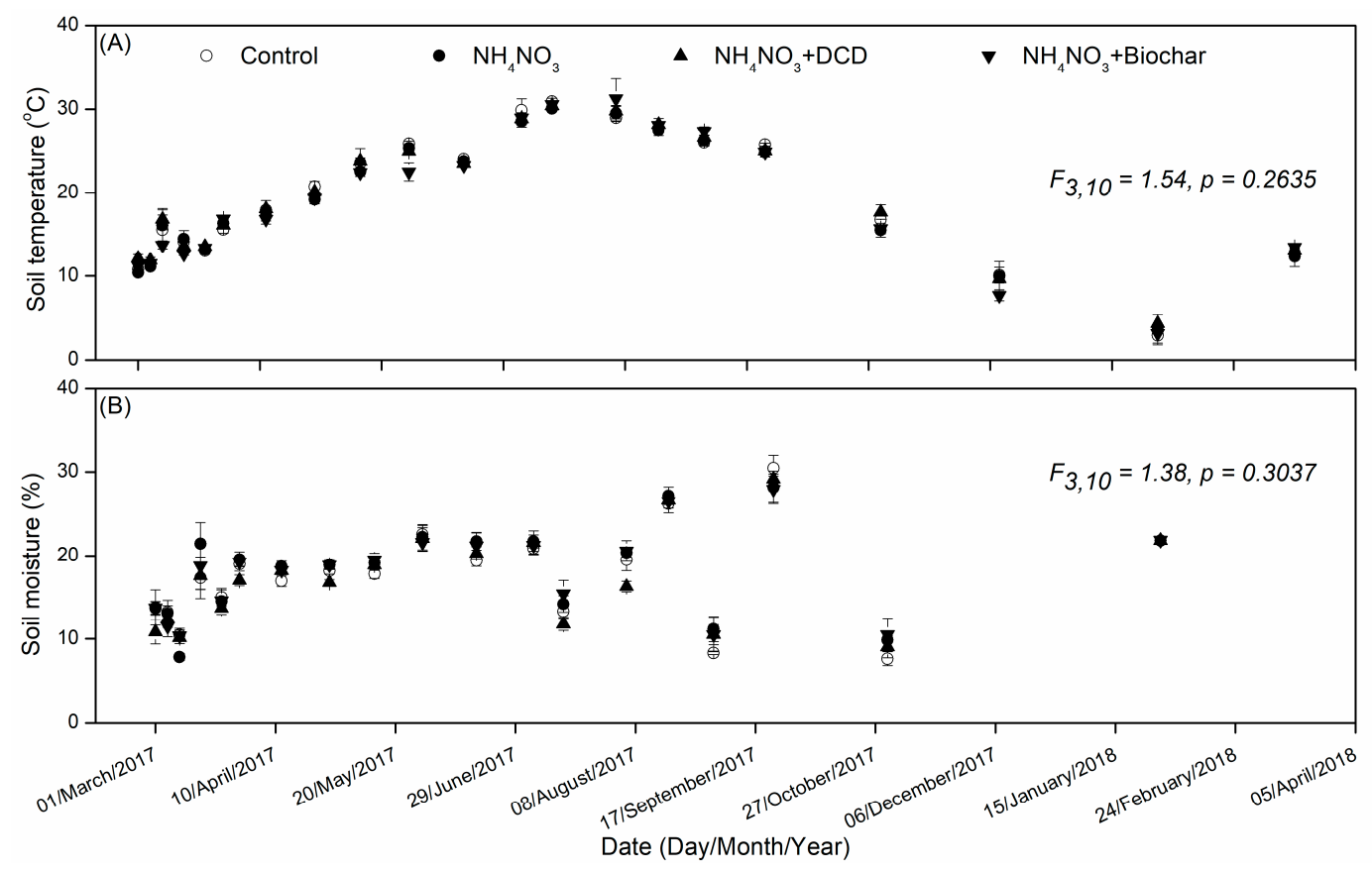

Figure 1. Soil (A) temperature and (B) moisture (mean \pm standard error) over the 12-month study in Camellia oleifera Abel. field with the $\mathrm{N}$ and mitigation treatments. Repeated-measure one-way analysis of variance results are shown. $\mathrm{N}$ : nitrogen; DCD: dicyandiamide; $\mathrm{NH}_{4} \mathrm{NO}_{3}$ : ammonium nitrate. 

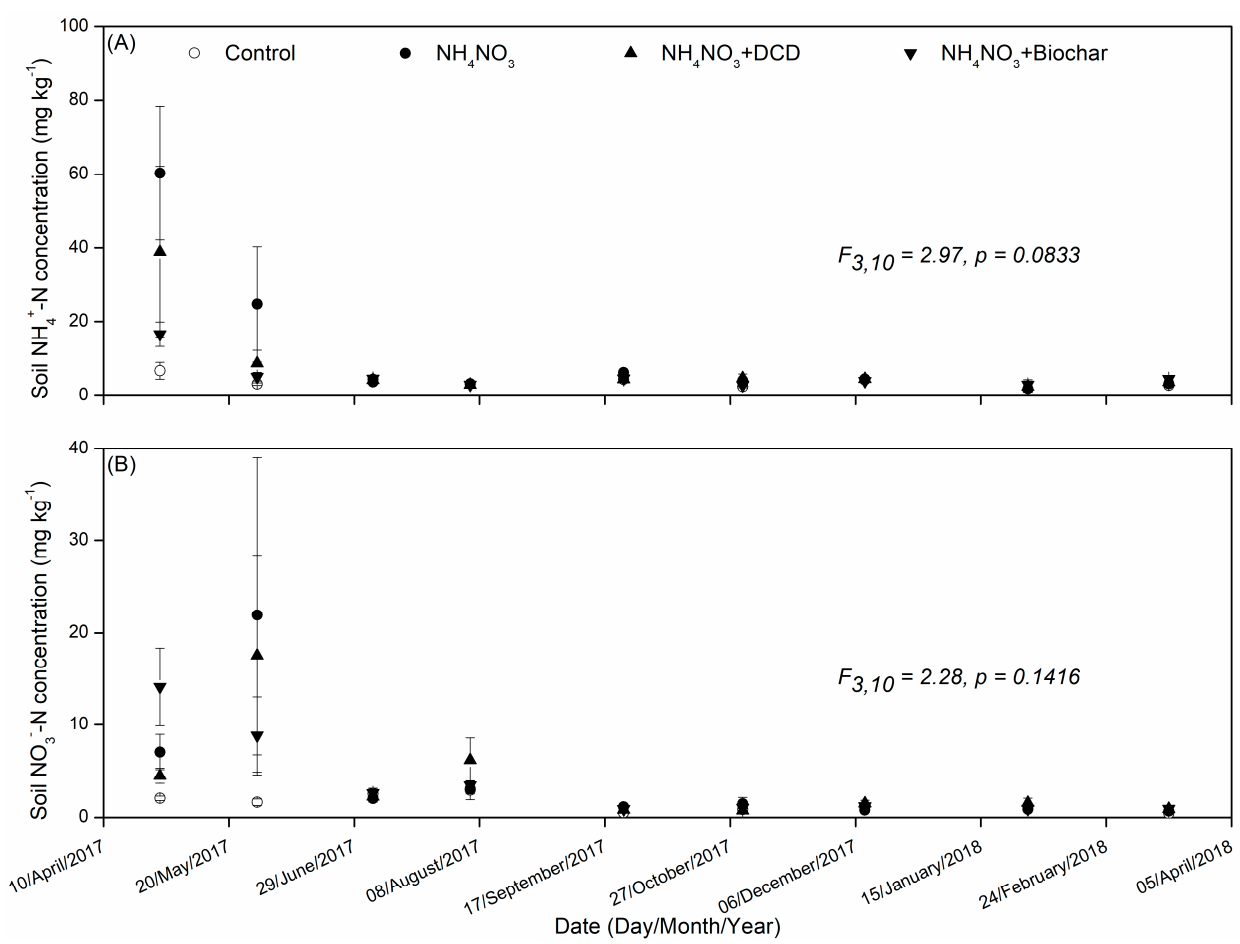

Figure 2. Soil inorganic $\mathrm{N}$ dynamics, including (A) $\mathrm{NH}_{4}{ }^{+}-\mathrm{N}$ and (B) $\mathrm{NO}_{3}{ }^{-}-\mathrm{N}$ (mean \pm standard error), over the 12-month study in Camellia oleifera Abel. field with the $\mathrm{N}$ and mitigation treatments. Repeated-measure one-way analysis of variance results are shown. $\mathrm{N}$ : nitrogen; $\mathrm{NH}_{4}{ }^{+}-\mathrm{N}$ : ammonium nitrogen; $\mathrm{NO}_{3}{ }^{-}-\mathrm{N}$ : nitrate nitrogen; DCD: dicyandiamide; $\mathrm{NH}_{4} \mathrm{NO}_{3}$ : ammonium nitrate.

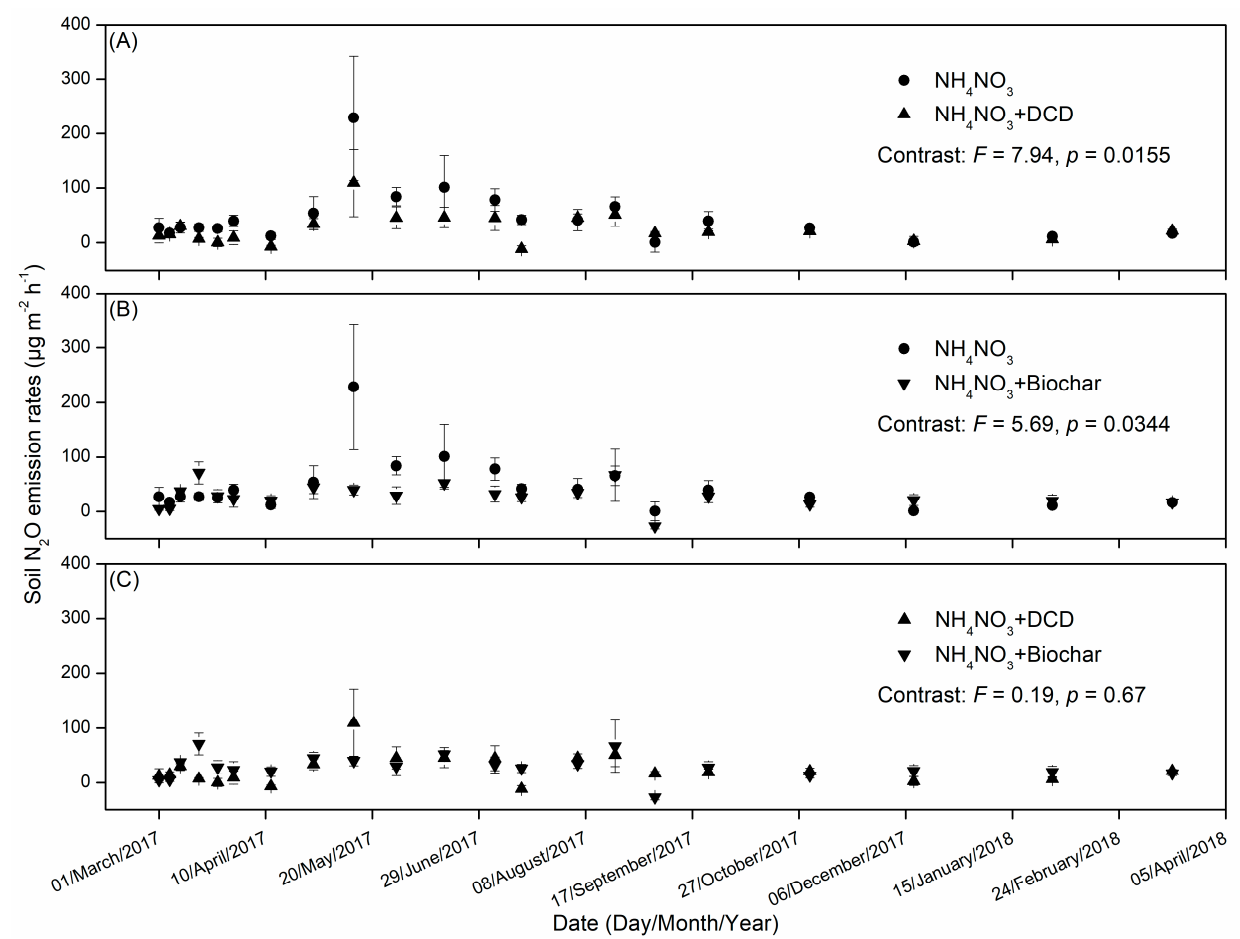

Figure 3. Soil $\mathrm{N}_{2} \mathrm{O}$ emissions (mean \pm standard error) from soil with $\mathrm{N}$, or $\mathrm{N}$ with $\mathrm{DCD}$ or biochar in a Camellia oleifera Abel. field. (A) $\mathrm{NH}_{4} \mathrm{NO}_{3}$ vs. $\mathrm{NH}_{4} \mathrm{NO}_{3}+$ DCD; (B) $\mathrm{NH}_{4} \mathrm{NO}_{3}$ vs. $\mathrm{NH}_{4} \mathrm{NO}_{3}+$ Biochar; (C) $\mathrm{NH}_{4} \mathrm{NO}_{3}+$ DCD vs. $\mathrm{NH}_{4} \mathrm{NO}_{3}+$ Biochar. Repeated-measure one-way analysis of variance and follow-up contrast results are shown. $\mathrm{N}$ : nitrogen; $\mathrm{DCD}$ : dicyandiamide; $\mathrm{NH}_{4} \mathrm{NO}_{3}$ : ammonium nitrate; $\mathrm{N}_{2} \mathrm{O}$ : nitrous oxide. 
Nitrogen treatment increased cumulative soil $\mathrm{N}_{2} \mathrm{O}$ emissions (control vs. $\mathrm{N}, 92.14 \pm 47.01$ vs. $375.10 \pm 60.30 \mathrm{mg} \mathrm{m}^{-2}$, respectively). DCD reduced the increase of cumulative soil $\mathrm{N}_{2} \mathrm{O}$ emissions caused by $\mathrm{N}$ addition, but no significant differences were observed between $\mathrm{N}+\mathrm{DCD}$ and $\mathrm{N}+$ biochar treatments (Figure 4, N + DCD vs. $\mathrm{N}+$ biochar, $211.89 \pm 35.88$ vs. $238.34 \pm 30.65 \mathrm{mg} \mathrm{m}^{-2}$ ). The soil $\mathrm{N}_{2} \mathrm{O}$ emission rate positively correlated with soil temperature, moisture, $\mathrm{NH}_{4}{ }^{+}-\mathrm{N}$, and $\mathrm{NO}_{3}{ }^{-}-\mathrm{N}$ (Table 1).

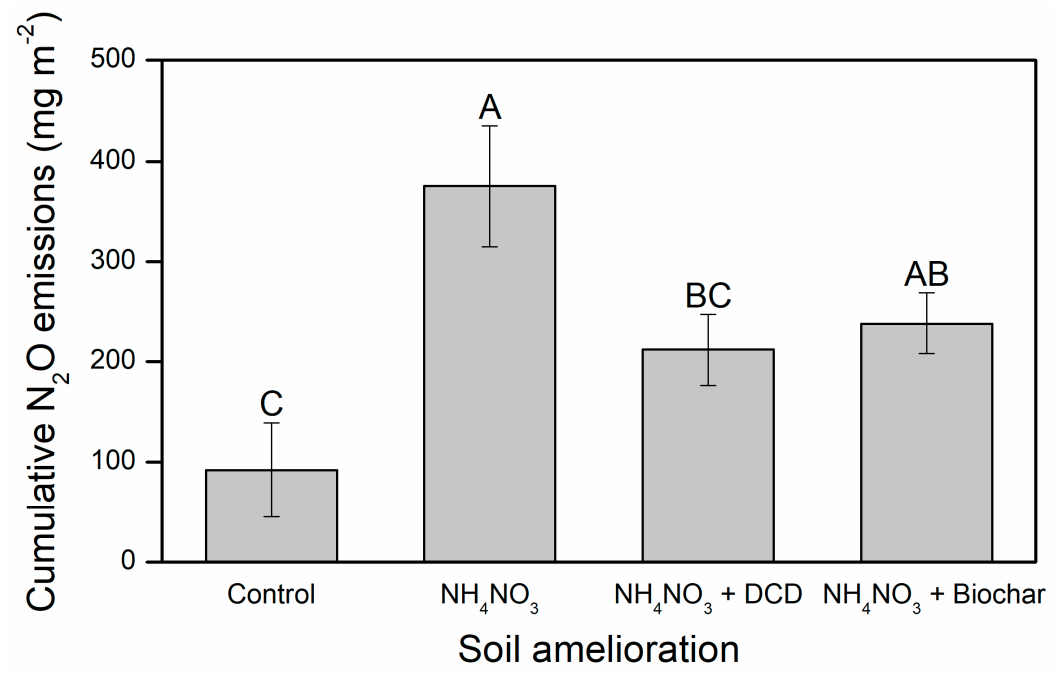

Figure 4. Cumulative soil $\mathrm{N}_{2} \mathrm{O}$ emissions (mean $\pm \mathrm{SE}$ ) from the Camellia oleifera Abel. field as affected by $\mathrm{N}$ fertilization, $\mathrm{DCD}$, or biochar treatments. Bars connected by the same letter are not significantly different in post-hoc tests at $\alpha=0.05$. $\mathrm{N}$ : nitrogen; $\mathrm{DCD}$ : dicyandiamide; $\mathrm{NH}_{4} \mathrm{NO}_{3}$ : ammonium nitrate; $\mathrm{N}_{2} \mathrm{O}$ : nitrous oxide.

Table 1. Pairwise correlations among soil environmental factors, inorganic nitrogen and soil $\mathrm{N}_{2} \mathrm{O}$ emission rate.

\begin{tabular}{ccccc}
\hline Parameters & Soil Temperature & Soil Moisture & $\mathbf{N H}_{4}{ }^{+}-\mathbf{N}$ & $\mathrm{NO}_{3}{ }^{-}-\mathbf{N}$ \\
\hline Soil moisture & $0.275^{* * *}$ & & \\
$\mathrm{NH}_{4}{ }^{+}-\mathrm{N}$ & 0.051 & -0.050 & \\
$\mathrm{NO}_{3}{ }^{-}-\mathrm{N}$ & $0.188^{*}$ & -0.003 & $0.414^{* * *}$ & \\
$\mathrm{~N}_{2} \mathrm{O}$ & $0.216^{* * *}$ & $0.201^{* * *}$ & $0.285^{* * *}$ & $0.221^{* *}$ \\
\hline${ }^{*}, p<0.05 ;{ }^{* *}, p<0.01 ;{ }^{* * *}, p<0.001 . \mathrm{NH}_{4}{ }^{*}-\mathrm{N}:$ ammonium nitrogen; $\mathrm{NO}_{3}{ }^{-}-\mathrm{N}:$ nitrate nitrogen; $\mathrm{N}_{2} \mathrm{O}:$ nitrous oxide.
\end{tabular}

\section{Discussion}

Nitrous oxide emitted from C. oleifera plantation was monitored over one year in situ study to investigate effects of biochar or DCD on soil $\mathrm{N}_{2} \mathrm{O}$ emissions following application of $\mathrm{N}$ fertilization. Soil $\mathrm{N}_{2} \mathrm{O}$ emission rates were decreased by biochar or DCD in fertilized soil and the decrease was comparable between two treatments (Figure 3). However, the cumulative soil $\mathrm{N}_{2} \mathrm{O}$ emissions caused by $\mathrm{NH}_{4} \mathrm{NO}_{3}$ fertilization were reduced by DCD application to levels comparable to the control treatment (Figure 4).

\subsection{Nitrogen Fertilization Stimulated Soil $\mathrm{N}_{2} \mathrm{O}$ Emissions}

Nitrogen fertilization stimulated cumulative soil $\mathrm{N}_{2} \mathrm{O}$ emissions from C. oleifera plantation (Figure 4). $\mathrm{N}$ fertilization generally alters activities of $\mathrm{N}$-transforming microorganisms via input of available $\mathrm{N}$ substrate [29], stimulating the processes of microbial-driven nitrification and denitrification and subsequent soil $\mathrm{N}_{2} \mathrm{O}$ emissions [30,31]. In general, soil $\mathrm{N}_{2} \mathrm{O}$ emissions were increased by $\mathrm{N}$ input with nonlinear responses [32]. Indeed, the soil $\mathrm{N}_{2} \mathrm{O}$ emission rate was positively correlated with $\mathrm{NH}_{4}{ }^{+}-\mathrm{N}$ and $\mathrm{NO}_{3}{ }^{-}-\mathrm{N}$ (Table 1). Furthermore, intensive $\mathrm{N}$ fertilization, especially $\mathrm{NH}_{4}{ }^{+}-\mathrm{N}$ fertilization, often results in soil acidification [33,34]. Changes in soil $\mathrm{pH}$ may regulate soil $\mathrm{N}_{2} \mathrm{O}$ emissions via 
altering the abundance and composition of N-transforming microorganisms [35-37]. For example, abundances of ammonia-oxidizing bacteria (AOB) were more sensitive to $\mathrm{N}$ addition than that of ammonia-oxidizing archaea (AOA) (+326\% vs. + 27\%) [35]. Soil acidification induced by intensive $\mathrm{N}$ fertilization results in a high ratio of $\mathrm{N}_{2} \mathrm{O} /\left(\mathrm{N}_{2} \mathrm{O}+\mathrm{N}_{2}\right)$ in the previous study [38]. Therefore, $\mathrm{N}$ addition might alter the abundance and composition of AOB and AOA via acidifying soil, hence stimulating $\mathrm{N}_{2} \mathrm{O}$ emissions.

In our study, positive correlations between $\mathrm{N}_{2} \mathrm{O}$ emission rate and soil temperature or soil moisture were observed (Table 1). A previous study demonstrated that soil temperature and moisture can explain up to $86 \%$ variations of $\mathrm{N}_{2} \mathrm{O}$ emissions [39]. Soil $\mathrm{N}_{2} \mathrm{O}$ emissions varied with soil temperature in specific ranges $[28,40]$, which may relate to different optimum temperatures of $\mathrm{N}$-transforming microorganisms with or without $\mathrm{N}$ fertilization and different soil types $[37,41]$. Compared with soil temperature, soil moisture is the main factor impacting soil $\mathrm{N}_{2} \mathrm{O}$ emissions. Consistently, soil $\mathrm{N}_{2} \mathrm{O}$ emitted from a wheat-maize plantation showed a positive correlation with a soil water-filled pore space (WFPS) [42]. However, higher soil moisture with lower oxygen content was beneficial to denitrification $[30,43]$ and potentially decrease soil $\mathrm{N}_{2} \mathrm{O}$ emissions [44,45]. For example, WFPS at $67-76 \%$ was the optimum moisture environment for emitting $\mathrm{N}_{2} \mathrm{O}$ [46]. Similarly, $\mathrm{N}_{2} \mathrm{O}$ emitted from a rice-rapeseed rotation soil was higher in 60\% WFPS than flooding in an incubation experiment [36]. Therefore, moisture effects of soil $\mathrm{N}_{2} \mathrm{O}$ emissions may depend on soil type and present non-linear correlations.

\subsection{Biochar Reduced Soil $\mathrm{N}_{2} \mathrm{O}$ Emission Rates as Affected by N Fertilization}

In fertilized soil, $\mathrm{N}_{2} \mathrm{O}$ emission rates were significantly decreased and cumulative $\mathrm{N}_{2} \mathrm{O}$ emissions were decreased by $36 \%$ by biochar (Figures 3B and 4), indicating biochar could be an ideal strategy for $\mathrm{N}_{2} \mathrm{O}$ mitigations in C. oleifera plantations with $\mathrm{N}$ fertilization. Indeed, soil $\mathrm{N}_{2} \mathrm{O}$ emissions with $\mathrm{N}$ fertilization were decreased $33 \%$ by biochar in a meta-analysis study [7]. Biochar-suppressed soil $\mathrm{N}_{2} \mathrm{O}$ emissions may be relative, limiting the availability of $\mathrm{NO}_{3}{ }^{-}-\mathrm{N}$ to denitrifiers $[47,48]$ or altering the $\mathrm{N}$ transformation process rather than limiting the availability of $\mathrm{NH}_{4}{ }^{+}-\mathrm{N}$ or $\mathrm{NO}_{3}{ }^{-}-\mathrm{N}$ to $\mathrm{N}$-transforming microorganisms [49]. In addition, biochar could also impose toxic effects on urease activity and subsequent generation of $\mathrm{NH}_{4}{ }^{+}-\mathrm{N}$ by introducing polycyclic aromatic hydrocarbons, heavy metals, and free radicals into soil [50], which may suppress soil $\mathrm{N}_{2} \mathrm{O}$ emissions via reducing the $\mathrm{N}$ substrate with respect to $\mathrm{N}$-transforming microorganisms.

Biochar addition may suppress soil $\mathrm{N}_{2} \mathrm{O}$ emissions by increasing soil $\mathrm{pH}$ [12]. The activity of $\mathrm{N}_{2} \mathrm{O}$-reductase was generally higher with higher soil $\mathrm{pH}$ [31]. Indeed, the $\mathrm{pH}$ of $C$. oleifera fruit shell-derived biochar was higher than that of the acid soil in C. oleifera plantations. While an acid soil improvement study showed that liming by dolomite addition could substantially mitigate $\mathrm{N}_{2} \mathrm{O}$ emissions via increasing nosZ gene abundance [36,51], biochar application could also increase soil $\mathrm{pH}$ of the acid $\mathrm{C}$. oleifera field soil, which might have also been accompanied by enhanced activities of $\mathrm{N}_{2} \mathrm{O}$-reducing enzymes and hence suppressed $\mathrm{N}_{2} \mathrm{O}$ emissions. Moreover, the negative effects of biochar on $\mathrm{N}_{2} \mathrm{O}$ emissions could also be induced by its buffer capacity rather than $\mathrm{pH}$, in which biochar acted as "electron shuttle" and replaced $\mathrm{NO}_{3}{ }^{-}$as electron sink during denitrification [52]. However, the application of $C$. oleifera fruit shell-derived biochar stimulated $\mathrm{N}_{2} \mathrm{O}$ emissions in a previous incubation study [22], which might have been caused by the short-term time scale of incubation study and further indicated the importance of in situ studies. Future studies are still needed for thoroughly understanding of $C$. oleifera fruit shell-derived biochar effects on $\mathrm{N}_{2} \mathrm{O}$ emissions and its prolonged effects in mitigation of soil $\mathrm{N}_{2} \mathrm{O}$ emissions.

\subsection{DCD Reduced Soil $\mathrm{N}_{2} \mathrm{O}$ Emissions as Affected by $\mathrm{N}$ Fertilization}

Cumulative soil $\mathrm{N}_{2} \mathrm{O}$ emissions were reduced $44 \%$ by DCD application in soil with $\mathrm{N}$ fertilization treatment (Figures 3A and 4), which indicated that the application of DCD is an effective strategy for mitigating soil $\mathrm{N}_{2} \mathrm{O}$ emissions in C. oleifera plantations with intensive $\mathrm{N}$ fertilization. DCD has been proved to be effective in reducing average $\mathrm{N}_{2} \mathrm{O}$ emission rates following $\mathrm{NH}_{4} \mathrm{NO}_{3}$ addition in a 
previous study [22]. In agreement, $\mathrm{DCD}$ reduced soil $\mathrm{N}_{2} \mathrm{O}$ emissions following $\left(\mathrm{NH}_{4}\right)_{2} \mathrm{SO}_{4}$ addition by suppressing $a m o A$ genes and stimulating nos $Z$ genes [53]. Nitrification and denitrification are two main pathways producing $\mathrm{N}_{2} \mathrm{O}[30,31,54]$. Application of nitrification inhibitors can suppress soil $\mathrm{N}_{2} \mathrm{O}$ emissions $[15,16]$ by inhibiting the activity of ammonium monooxygenase enzyme involved in nitrification process [16]. Thereby, application of DCD generally decreases abundance of $a m o A$ genes and hence soil $\mathrm{N}_{2} \mathrm{O}$ emissions.

\subsection{Biochar and DCD Effects on Soil $\mathrm{N}_{2} \mathrm{O}$ Emissions}

While $\mathrm{N}$ fertilization significantly increased soil $\mathrm{N}_{2} \mathrm{O}$ emissions compared with control treatment, DCD application decreased soil $\mathrm{N}_{2} \mathrm{O}$ emissions to similar levels as control treatment (Figures $3 \mathrm{~A}$ and 4 ). Even though biochar addition treatment did not significantly decrease $\mathrm{N}_{2} \mathrm{O}$ emissions from soil with $\mathrm{N}$, the slight decrease in cumulative $\mathrm{N}_{2} \mathrm{O}$ emissions may potentially mitigate $\mathrm{N}_{2} \mathrm{O}$ emissions in prolonged study, which should be examined in future studies. However, DCD application significantly decreased cumulative $\mathrm{N}_{2} \mathrm{O}$ emissions and no significant difference was observed between control and DCD treatment (Figure 4), indicating DCD was effective in mitigation of $\mathrm{N}_{2} \mathrm{O}$ emissions from C. oleifera field relative to biochar. No significant differences were observed between DCD and biochar treatments in their effects on $\mathrm{N}_{2} \mathrm{O}$ emission rates (Figures $3 \mathrm{C}$ and 4), indicating biochar application could be considered as a potential mitigation strategy of soil $\mathrm{N}_{2} \mathrm{O}$. Similarly, both DCD and biochar reduced the yield-scaled $\mathrm{N}_{2} \mathrm{O}$ following $\mathrm{N}$ fertilization, while biochar showed stronger effects than DCD in $\mathrm{N}_{2} \mathrm{O}$ mitigation in a sweet corn field [55].

\section{Conclusions}

This study is the first in examining the effects of DCD and biochar derived from C. oleifera fruit shells on mitigation of soil $\mathrm{N}_{2} \mathrm{O}$ emissions. Application of biochar and DCD showed comparable effects in mitigation of the $\mathrm{N}_{2} \mathrm{O}$ emission rate in a C. oleifera field with intensive $\mathrm{N}$ fertilization practice, with biochar slightly decreasing and DCD significantly decreasing cumulative $\mathrm{N}_{2} \mathrm{O}$ emissions. This might have implications for the disposal of dumped byproducts in management of $C$. oleifera and represent an ideal way to enhance both the economic and ecological benefits of the C. oleifera industry. If this pattern presents in other plantations, the combined effects of biochar and nitrification inhibitors on soil $\mathrm{N}_{2} \mathrm{O}$ emissions should be focused upon in the future. However, the potential effects of biochar derived from $C$. oleifera fruit shell on cumulative $\mathrm{N}_{2} \mathrm{O}$ emissions in prolonged studies and other kinds of ecosystems should be examined in future in order to provide guidance for intensive management of C. oleifera plantations and disposal of byproducts.

Author Contributions: Conceptualization, L.Z. and B.D.; methodology, L.Z. and B.D.; software, L.Z. and B.D.; validation, H.F., N.J., H.W., and D.H.; investigation, B.D., H.F., and N.J.; resources, L.Z. and X.G.; data curation, B.D., H.F., N.J., and J.W.; writing-original draft preparation, B.D.; writing-review and editing, L.Z., N.J., H.W., J.W., W.F., L.L., and X.G.; project administration, B.D., H.F., and L.Z.; funding acquisition, L.Z.

Funding: This research was funded by the National Natural Science Foundation of China, Grant Numbers 41967017 and 41501317, and the Jiangxi Education Department, Project Number GJJ160348. Bangliang Deng was supported by China Scholarship Council for study in the United States.

Acknowledgments: Thanks are given to Liya Zheng, Xiang Zheng, Qian Li, Xi Yuan, Shuli Wang, Xintong Xu, and Jianwei Wang for their help in laboratory and field work.

Conflicts of Interest: The authors have declared that no competing interests exist.

\section{References}

1. IPCC. Synthesis Report, Climate Change 2014; IPCC: Geneva, Switzerland, 2014; pp. 1-164.

2. Ravishankara, A.R.; Daniel, J.S.; Portmann, R.W. Nitrous oxide $\left(\mathrm{N}_{2} \mathrm{O}\right)$ : The dominant ozone-depleting substance emitted in the 21st century. Science 2009, 326, 123-125. [CrossRef] [PubMed]

3. WMO. WMO Greenhouse Gas Bulletin: The State of Greenhouse Gases in the Atmosphere Based on Global Observations Through 2017; Atmospheric Environment Research Division: Geneva, Switzerland, 2018; pp. 1-8. 
4. Fowler, D.; Coyle, M.; Skiba, U.; Sutton, M.A.; Cape, J.N.; Reis, S.; Sheppard, L.J.; Jenkins, A.; Grizzetti, B.; Galloway, J.N.; et al. The global nitrogen cycle in the twenty-first century. Philos. Trans. R. Soc. B Biol. Sci. 2013, 368, 1-13. [CrossRef]

5. Gerber, J.S.; Carlson, K.M.; Makowski, D.; Mueller, N.D.; Garcia De Cortazar-Atauri, I.; Havlík, P.; Herrero, M.; Launay, M.; O'Connell, C.S.; Smith, P.; et al. Spatially explicit estimates of $\mathrm{N}_{2} \mathrm{O}$ emissions from croplands suggest climate mitigation opportunities from improved fertilizer management. Glob. Chang. Biol. 2016, 22, 3383-3394. [CrossRef] [PubMed]

6. Carlson, K.M.; Gerber, J.S.; Mueller, N.D.; Herrero, M.; MacDonald, G.K.; Brauman, K.A.; Havlik, P.; Connell, C.S.; Johnson, J.A.; Saatchi, S.; et al. Greenhouse gas emissions intensity of global croplands. Nat. Clim. Chang. 2017, 7, 63-68. [CrossRef]

7. He, Y.; Zhou, X.; Jiang, L.; Li, M.; Du, Z.; Zhou, G.; Shao, J.; Wang, X.; Xu, Z.; Hosseini Bai, S.; et al. Effects of biochar application on soil greenhouse gas fluxes: A meta-analysis. GCB Bioenergy 2017, 9, 743-755. [CrossRef]

8. Gu, J.; Nie, H.; Guo, H.; Xu, H.; Gunnathorn, T. Nitrous oxide emissions from fruit orchards: A review. Atmos. Environ. 2019, 201, 166-172. [CrossRef]

9. Liu, Q.; Liu, B.; Zhang, Y.; Hu, T.; Lin, Z.; Liu, G.; Wang, X.; Ma, J.; Wang, H.; Jin, H.; et al. Biochar application as a tool to decrease soil nitrogen losses $\left(\mathrm{NH}_{3}\right.$ volatilization, $\mathrm{N}_{2} \mathrm{O}$ emissions, and $\mathrm{N}$ leaching) from croplands: Options and mitigation strength in a global perspective. Glob. Chang. Biol. 2019, 25, 2077-2093. [CrossRef]

10. Shrestha, B.; Chang, S.; Bork, E.; Carlyle, C. Enrichment planting and soil amendments enhance carbon sequestration and reduce greenhouse gas emissions in agroforestry systems: A review. Forests 2018, 9, 369. [CrossRef]

11. Johannes, L.; Stephen, J. Biochar for Environmental Management; Routledge: New York, NY, USA, 2015; pp. 1-944.

12. Obia, A.; Cornelissen, G.; Mulder, J.; Dörsch, P. Effect of soil pH increase by biochar on $\mathrm{NO}, \mathrm{N}_{2} \mathrm{O}$ and $\mathrm{N}_{2}$ production during denitrification in acid soils. PLOS ONE 2015, 10, 1-19. [CrossRef]

13. Zakir, H.A.; Subbarao, G.V.; Pearse, S.J.; Gopalakrishnan, S.; Ito, O.; Ishikawa, T.; Kawano, N.; Nakahara, K.; Yoshihashi, T.; Ono, H.; et al. Detection, isolation and characterization of a root-exuded compound, methyl 3-(4-hydroxyphenyl) propionate, responsible for biological nitrification inhibition by sorghum (Sorghum bicolor). New Phytol. 2008, 180, 442-451. [CrossRef]

14. Subbarao, G.V.; Nakahara, K.; Hurtado, M.P.; Ono, H.; Moreta, D.E.; Salcedo, A.F.; Yoshihashi, A.T.; Ishikawa, T.; Ishitani, M.; Ohnishi-Kameyama, M.; et al. Evidence for biological nitrification inhibition in Brachiaria pastures. Proc. Natl. Acad. Sci. USA 2009, 106, 17302-17307. [CrossRef] [PubMed]

15. Qiao, C.; Liu, L.; Hu, S.; Compton, J.E.; Greaver, T.L.; Li, Q. How inhibiting nitrification affects nitrogen cycle and reduces environmental impacts of anthropogenic nitrogen input. Glob. Chang. Biol. 2015, 21, 1249-1257. [CrossRef] [PubMed]

16. Ruser, R.; Schulz, R. The effect of nitrification inhibitors on the nitrous oxide $\left(\mathrm{N}_{2} \mathrm{O}\right)$ release from agricultural soils-a review. J. Plant Nutr. Soil Sci. 2015, 178, 171-188. [CrossRef]

17. Liu, J.; Wu, L.; Chen, D.; Li, M.; Wei, C. Soil quality assessment of different Camellia oleifera stands in mid-subtropical China. Appl. Soil Ecol. 2017, 113, 29-35. [CrossRef]

18. Yuan, J.; Wang, C.; Chen, H.; Zhou, H.; Ye, J. Prediction of fatty acid composition in Camellia oleifera oil by near infrared transmittance spectroscopy (NITS). Food Chem. 2013, 138, 1657-1662. [CrossRef]

19. Liu, C.; Chen, L.; Tang, W.; Peng, S.; Li, M.; Deng, N.; Chen, Y. Predicting potential distribution and evaluating suitable soil condition of oil tea Camellia in China. Forests 2018, 9, 487. [CrossRef]

20. Martins, M.R.; Sant Anna, S.A.C.; Zaman, M.; Santos, R.C.; Monteiro, R.C.; Alves, B.J.R.; Jantalia, C.P.; Boddey, R.M.; Urquiaga, S. Strategies for the use of urease and nitrification inhibitors with urea: Impact on $\mathrm{N}_{2} \mathrm{O}$ and $\mathrm{NH}_{3}$ emissions, fertilizer- ${ }^{15} \mathrm{~N}$ recovery and maize yield in a tropical soil. Agric. Ecosyst. Environ. 2017, 247, 54-62. [CrossRef]

21. Liu, S.; Lin, F.; Wu, S.; Ji, C.; Sun, Y.; Jin, Y.; Li, S.; Li, Z.; Zou, J. A meta-analysis of fertilizer-induced soil NO and combined $\mathrm{NO}+\mathrm{N}_{2} \mathrm{O}$ emissions. Glob. Chang. Biol. 2017, 23, 2520-2532. [CrossRef]

22. Deng, B.; Wang, S.; Xu, X.; Wang, H.; Hu, D.; Guo, X.; Shi, Q.; Siemann, E.; Zhang, L. Effects of biochar and dicyandiamide combination on nitrous oxide emissions from Camellia oleifera field soil. Environ. Sci. Pollut. Res. 2019, 26, 4070-4077. [CrossRef] 
23. Zhang, L.; Wang, S.; Liu, S.; Liu, X.; Zou, J.; Siemann, E. Perennial forb invasions alter greenhouse gas balance between ecosystem and atmosphere in an annual grassland in China. Sci. Total Environ. 2018, 642, 781-788. [CrossRef]

24. Zhang, L.; Ma, X.; Wang, H.; Liu, S.; Siemann, E.; Zou, J. Soil respiration and litter decomposition increased following perennial forb invasion into an annual grassland. Pedosphere 2016, 26, 567-576. [CrossRef]

25. Carter, M.R.; Gregorich, E.G. Soil Sampling and Methods of Analysis; CRC Press: Boca Raton, IL, USA, 2007; pp. 1-1224.

26. Pärn, J.; Verhoeven, J.T.A.; Butterbach-Bahl, K.; Dise, N.B.; Ullah, S.; Aasa, A.; Egorov, S.; Espenberg, M.; Järveoja, J.; Jauhiainen, J.; et al. Nitrogen-rich organic soils under warm well-drained conditions are global nitrous oxide emission hotspots. Nat. Commun. 2018, 9, 1-8. [CrossRef]

27. Domeignoz-Horta, L.A.; Philippot, L.; Peyrard, C.; Bru, D.; Breuil, M.; Bizouard, F.; Justes, E.; Mary, B.; Léonard, J.; Spor, A. Peaks of in situ $\mathrm{N}_{2} \mathrm{O}$ emissions are influenced by $\mathrm{N}_{2} \mathrm{O}$-producing and reducing microbial communities across arable soils. Glob. Chang. Biol. 2018, 24, 360-370. [CrossRef] [PubMed]

28. He, T.; Yuan, J.; Luo, J.; Wang, W.; Fan, J.; Liu, D.; Ding, W. Organic fertilizers have divergent effects on soil $\mathrm{N}_{2} \mathrm{O}$ emissions. Biol. Fertil. Soils 2019, 55, 685-699. [CrossRef]

29. Lourenço, K.S.; Dimitrov, M.R.; Pijl, A.; Soares, J.R.; Do Carmo, J.B.; van Veen, J.A.; Cantarella, H.; Kuramae, E.E. Dominance of bacterial ammonium oxidizers and fungal denitrifiers in the complex nitrogen cycle pathways related to nitrous oxide emission. GCB Bioenergy 2018, 10, 645-660. [CrossRef]

30. Pauleta, S.R.; Dell Acqua, S.; Moura, I. Nitrous oxide reductase. Coord. Chem. Rev. 2013, 257, 332-349. [CrossRef]

31. Hu, H.; Chen, D.; He, J. Microbial regulation of terrestrial nitrous oxide formation: Understanding the biological pathways for prediction of emission rates. FEMS Microbiol. Rev. 2015, 39, 729-749. [CrossRef]

32. Shcherbak, I.; Millar, N.; Robertson, G.P. Global metaanalysis of the nonlinear response of soil nitrous oxide $\left(\mathrm{N}_{2} \mathrm{O}\right)$ emissions to fertilizer nitrogen. Proc. Natl. Acad. Sci. USA 2014, 111, 9199-9204. [CrossRef]

33. Tian, D.; Niu, S. A global analysis of soil acidification caused by nitrogen addition. Environ. Res. Lett. 2015, 10, 24019. [CrossRef]

34. Matson, P.A.; McDowell, W.H.; Townsend, A.R.; Vitousek, P.M. The globalization of N deposition: Ecosystem consequences in tropical environments. Biogeochemistry 1999, 46, 67-83. [CrossRef]

35. Carey, C.J.; Dove, N.C.; Beman, J.M.; Hart, S.C.; Aronson, E.L. Meta-analysis reveals ammonia-oxidizing bacteria respond more strongly to nitrogen addition than ammonia-oxidizing archaea. Soil Biol. Biochem. 2016, 99, 158-166. [CrossRef]

36. Shaaban, M.; Wu, Y.; Khalid, M.S.; Peng, Q.; Xu, X.; Wu, L.; Younas, A.; Bashir, S.; Mo, Y.; Lin, S.; et al. Reduction in soil $\mathrm{N}_{2} \mathrm{O}$ emissions by $\mathrm{pH}$ manipulation and enhanced nosZ gene transcription under different water regimes. Environ. Pollut. 2018, 235, 625-631. [CrossRef] [PubMed]

37. Blum, J.; Su, Q.; Ma, Y.; Valverde-Pérez, B.; Domingo-Félez, C.; Jensen, M.M.; Smets, B.F. The pH dependency of $\mathrm{N}$-converting enzymatic processes, pathways and microbes: Effect on net $\mathrm{N}_{2} \mathrm{O}$ production. Environ. Microbiol. 2018, 20, 1623-1640. [CrossRef] [PubMed]

38. Qu, Z.; Wang, J.; Almøy, T.; Bakken, L.R. Excessive use of nitrogen in Chinese agriculture results in high $\mathrm{N}_{2} \mathrm{O} /\left(\mathrm{N}_{2} \mathrm{O}+\mathrm{N}_{2}\right)$ product ratio of denitrification, primarily due to acidification of the soils. Glob. Chang. Biol. 2014, 20, 1685-1698. [CrossRef]

39. Schindlbacher, A. Effects of soil moisture and temperature on $\mathrm{NO}, \mathrm{NO}_{2}$, and $\mathrm{N}_{2} \mathrm{O}$ emissions from European forest soils. J. Geophys. Res. 2004, 109, 1-12. [CrossRef]

40. Pinheiro, P.L.; Recous, S.; Dietrich, G.; Weiler, D.A.; Schu, A.L.; Bazzo, H.L.S.; Giacomini, S.J. N ${ }_{2}$ O emission increases with mulch mass in a fertilized sugarcane cropping system. Biol. Fertil. Soils 2019, 55, 511-523. [CrossRef]

41. Yin, C.; Fan, F.; Song, A.; Fan, X.; Ding, H.; Ran, W.; Qiu, H.; Liang, Y. The response patterns of community traits of $\mathrm{N}_{2} \mathrm{O}$ emission-related functional guilds to temperature across different arable soils under inorganic fertilization. Soil Biol. Biochem. 2017, 108, 65-77. [CrossRef]

42. Chen, T.; Oenema, O.; Li, J.; Misselbrook, T.; Dong, W.; Qin, S.; Yuan, H.; Li, X.; Hu, C. Seasonal variations in $\mathrm{N}_{2}$ and $\mathrm{N}_{2} \mathrm{O}$ emissions from a wheat-maize cropping system. Biol. Fertil. Soils 2019, 55, 539-551. [CrossRef]

43. Quick, A.M.; Reeder, W.J.; Farrell, T.B.; Tonina, D.; Feris, K.P.; Benner, S.G. Nitrous oxide from streams and rivers: A review of primary biogeochemical pathways and environmental variables. Earth-Sci. Rev. 2019, 191, 224-262. [CrossRef] 
44. Chen, H.; Mothapo, N.V.; Shi, W. Soil moisture and $\mathrm{pH}$ control relative contributions of fungi and bacteria to $\mathrm{N}_{2} \mathrm{O}$ production. Microb. Ecol. 2015, 69, 180-191. [CrossRef]

45. Burgin, A.J.; Groffman, P.M. Soil $\mathrm{O}_{2}$ controls denitrification rates and $\mathrm{N}_{2} \mathrm{O}$ yield in a riparian wetland. J. Geophys. Res. Biogeosci. 2012, 117, 1-10. [CrossRef]

46. Chen, Z.; Ding, W.; Xu, Y.; Müller, C.; Yu, H.; Fan, J. Increased $\mathrm{N}_{2} \mathrm{O}$ emissions during soil drying after waterlogging and spring thaw in a record wet year. Soil Biol. Biochem. 2016, 101, 152-164. [CrossRef]

47. Van Zwieten, L.; Singh, B.P.; Kimber, S.W.L.; Murphy, D.V.; Macdonald, L.M.; Rust, J.; Morris, S. An incubation study investigating the mechanisms that impact $\mathrm{N}_{2} \mathrm{O}$ flux from soil following biochar application. Agric. Ecosyst. Environ. 2014, 191, 53-62. [CrossRef]

48. Case, S.D.C.; McNamara, N.P.; Reay, D.S.; Whitaker, J. The effect of biochar addition on $\mathrm{N}_{2} \mathrm{O}$ and $\mathrm{CO}_{2}$ emissions from a sandy loam soil - The role of soil aeration. Soil Biol. Biochem. 2012, 51, 125-134. [CrossRef]

49. Case, S.D.C.; McNamara, N.P.; Reay, D.S.; Stott, A.W.; Grant, H.K.; Whitaker, J. Biochar suppresses $\mathrm{N}_{2} \mathrm{O}$ emissions while maintaining $\mathrm{N}$ availability in a sandy loam soil. Soil Biol. Biochem. 2015, 81, 178-185. [CrossRef]

50. Liu, Y.; Dai, Q.; Jin, X.; Dong, X.; Peng, J.; Wu, M.; Liang, N.; Pan, B.; Xing, B. Negative impacts of biochars on urease activity: High $\mathrm{pH}$, heavy metals, polycyclic aromatic hydrocarbons, or free radicals? Environ. Sci. Technol. 2018, 52, 12740-12747. [CrossRef]

51. Shaaban, M.; Hu, R.; Wu, Y.; Younas, A.; Xu, X.; Sun, Z.; Jiang, Y.; Lin, S. Mitigation of $\mathrm{N}_{2} \mathrm{O}$ emissions from urine treated acidic soils by liming. Environ. Pollut. 2019, 225, 113237. [CrossRef]

52. Cayuela, M.L.; Sánchez-Monedero, M.A.; Roig, A.; Hanley, K.; Enders, A.; Lehmann, J. Biochar and denitrification in soils: When, how much and why does biochar reduce $\mathrm{N}_{2} \mathrm{O}$ emissions? Sci. Rep. 2013, 3, 1-7. [CrossRef]

53. Wang, Q.; Hu, H.W.; Shen, J.P.; Du, S.; Zhang, L.M.; He, J.Z.; Han, L.L. Effects of the nitrification inhibitor dicyandiamide (DCD) on $\mathrm{N}_{2} \mathrm{O}$ emissions and the abundance of nitrifiers and denitrifiers in two contrasting agricultural soils. J. Soils Sediments 2017, 17, 1635-1643. [CrossRef]

54. Kuypers, M.M.M.; Marchant, H.K.; Kartal, B. The microbial nitrogen-cycling network. Nat. Rev. Microbiol. 2018, 16, 263-276. [CrossRef]

55. Yi, Q.; Tang, S.; Fan, X.; Zhang, M.; Pang, Y.; Huang, X.; Huang, Q. Effects of nitrogen application rate, nitrogen synergist and biochar on nitrous oxide emissions from vegetable field in south China. PLOS ONE 2017, 12, 1-15. [CrossRef] 